\title{
Cervicomedullary Junction
}

National Cancer Institute

\section{Source}

National Cancer Institute. Cervicomedullary Junction. NCI Thesaurus. Code C12973.

The point at the base of the skull where the brainstem and cervical spine intersect. 